\title{
3D Printer Selection by Using Fuzzy Analytic Hierarchy Process and PROMETHEE
}

\author{
Cihan ÇETINKAYA ${ }^{1}$, Mehmet KABAK ${ }^{2}$, Eren ÖZCEYLAN ${ }^{3}$ \\ ${ }^{1}$ Department of Industrial Engineering, Gaziantep University, 27310, Gaziantep, Turkey \\ ${ }^{2}$ Department of Industrial Engineering, Gazi University, 06500, Ankara, Turkey \\ cihancetinkaya@gmail.com, mehmetkbk@gmail.com, erenozceylan@gmail.com \\ (Geliș/Received:11.01.2017; Kabul/Accepted:22.08.2017) \\ DOI: $10.17671 /$ gazibtd. 347610
}

\begin{abstract}
A 3D printer is a device which is used to produce three-dimensional objects from a digital 3D file. The 3D printers were very expensive and not really affordable for the general public so they were being used only by firms. But nowadays, 3D printers are more accessible to the public with competitive prices and many different models. This situation reveals the problem of choosing the best alternative among these printers. In this paper, we handle the 3D printer selection problem of a company which is in 3D production business. Since there is no study in literature that uses a hybrid Fuzzy AHP and PROMETHEE for selecting a 3D printer, it is believed that this paper can help the decision makers about their 3D printer selection decisions. Another importance of the paper can be introduced as being a real life guide for a real life problem of a company. To solve the problem, firstly the selection criteria are obtained from the company. Then, selection criteria are prioritized using Fuzzy Analytic Hierarchy Process (FAHP) and potential 3D printers are ranked using PROMETHEE. Finally, the best 3D printer is chosen for the company among five close alternatives.
\end{abstract}

Keywords - 3D printer, Fuzzy AHP, PROMETHEE, Additive manufacturing

\section{Bulanık Analitik Hiyerarşi Prosesi ve PROMETHEE Yöntemi İle 3D Yazıcı Seçimi}

$\ddot{O}_{z e t}$ - 3B yazıcılar, dijital ortamda bulunan ürün dosyalarını kullanarak 3 boyutlu cisimlerin üretiminin gerçekleştirildiği yazıcılardır. Piyasaya sürüldükleri ilk zamanlarda 3B yazıcılar sadece büyük işletmeler tarafından kullanılan çok pahalı cihazlardı. Ancak zamanla 3B yazıcı üreticilerinin sayılarının artması ile artan rekabet ortamında bir yandan yazıcı çeşitleri artmış diğer taraftan da satış fiyatları düşmüştür. Yazıcı sayılarının ve çeşitlerinin artması ise en uygun yazıcı tipinin seçimi gibi bir problemin ortaya çıkmasına sebep olmuştur. Bu çalışmada, 3B yazıcı sektöründe faaliyet gösteren bir işletme için alternatifler arasından en iyi 3B yazıcı seçim problemi ele alınmıştır. 3B yazıcı seçimi için bulanık analitik hiyerarşi süreci (AHS) ve PROMETHEE yöntemlerinin kullanıldığı melez bir çalışmaya literatürde rastlanılmadığı için bu çalışmanın karar vericilerin söz konusu probleme yaklaşımlarına yardımcı olacağına inanılmaktadır. Çalışmanın diğer bir önemli noktası ise gerçek hayat problemine çözüm aramasıdır. Bu çalışmada 3 aşamalı bir çözüm yaklaşımı uygulanmıştır. İlk aşamada 3B yazıcı seçiminde dikkat edilmesi gereken kriterler netleştirilmiştir. İkinci aşamada söz konusu kriterler bulanık AHS yöntemi ile ağırlıklandırılmış, alternatif 3B yazıcılar ise PROMETHEE yöntemi ile sıralanmıştır. Son aşamada ise, en iyi 3B yazıcı 5 alternatif arasından seçilmiştir.

Anahtar kelimeler - 3D yazıc1, Bulanık AHS, PROMETHEE, Eklemeli üretim

\section{INTRODUCTION}

Additive manufacturing (AM), also known as 3D printing, means turning a digital model to an object by building them layer-by-layer. This differs from conventional processes such as subtractive processes (i.e., milling or drilling), formative processes (i.e., casting or forging), and joining processes (i.e., welding or fastening) [1] Additive manufacturing has received tremendous attention recently. According to Wohlers Report 2014, the worldwide 3D printing industry is expected to grow from $\$ 3.07$ billion in revenue in 2013 to $\$ 12.8$ billion by 2018 , and exceed $\$ 21$ billion in worldwide revenue by 2020 [2].

While 3D printers work in a manner similar to traditional laser or inkjet printers, rather than using multi-colored inks, the 3D printer uses powder that is slowly built into an image on a layer-by-layer basis. All 3D printers also use 3D CAD software that measures thousands of crosssections of each product to determine exactly how each 
layer is to be constructed. The 3D machine dispenses a thin layer of liquid resin and uses a computer-controlled ultraviolet laser to harden each layer in the specified cross-section pattern. At the end of the process, excess soft resin is cleaned away through use of a chemical bath. $3 \mathrm{D}$ printers can produce simple objects, such as a gear, in less than 1 hour [3]. There are a lot of 3D printers on the market today that have varying specifications, which in turn cater to different demands. There are a few elements to consider when it comes to select the best 3D printer. The first one is generally the budget. Various 3D printers come with different costs and hence the budget is affected. The production speed of the printer and the filament diameter can be among other acceptable criteria. In this context, multi-criteria decision analysis technique can be used as a decision making tool [4].

In this paper, the $3 \mathrm{D}$ printer selection problem of a company which is in $3 \mathrm{D}$ production business in Gaziantep/Turkey currently is taken into account. To solve the problem, firstly the selection criteria are obtained from the company. Then, selection criteria are prioritized using Fuzzy Analytic Hierarchy Process (FAHP) and potential 3D printers are ranked using PROMETHEE. The paper is organized as follows; first section defines the problem followed by the second section which includes the related literature. Third section gives details about our methodology, while fourth section contains details about the computational analysis respectively. Conclusion section summarizes the study and discusses further areas for this study.

\section{LITERATURE REVIEW}

The related literature of this paper can be examined in two different sections. First mention about the methodology related literature that we apply on this study then we focus on the main topic of this paper.

\subsection{The methodology related literature}

Since we use Fuzzy Analytic Hierarchy Process and PROMETHEE in this paper as our tools, we focus on the papers conducted with the same methodology in this section of the literature. Rao and Patel [4] examine the decision makers in manufacturing sector. Their paper helps to understand and solve this important decision problem using AHP and the fuzzy logic integrated with PROMETHEE. The suggested methodology can be used for any type of selection problem involving any number of selection criteria. Then, Alp et al. [5] examines the garage location selection problem for a firm in urban passenger transport sector in Istanbul. The criteria are determined first and then the problem is solved using multi-criteria decision making techniques. They use fuzzy AHP for the weights of all sub-criteria and after that they use these weights in the PROMETHEE for ranking. Later, Brajlih et al. [6] aims to establish a general method for evaluation of AM machines. They define a schematic that enables description of all currently available AM machines. Their method is used to test four different machines that are predominantly used in Slovenia at that moment. Research has proven that the machine's yield had a predominant influence on the achievable manufacturing speeds of all the tested machines.

Taha and Rostam [7] present a decision support system to select the best alternative machine using a hybrid approach of fuzzy AHP and PROMETHEE. A MATLAB- based fuzzy AHP is used to determine the weights of the criteria and the PROMETHEE method is applied for the final ranking. The proposed model is structured to select the most suitable computer numerical controlled turning centre machine for a flexible manufacturing cell among the alternatives which are assigned from a database created for this purpose. It is concluded that the proposed model has the capability of dealing with a wide range of desired criteria and to select any type of machine tool required for building an FMC. Avikal et al. [8] proposes a heuristic to assign the disassembly tasks/parts to the work stations under its precedence constraints. It incorporates fuzzy AHP and PROMETHEE method for the selection of tasks for assignment to the disassembly line. The Fuzzy AHP has been used to find the relative importance of each criteria and PROMETHEE method has been used for prioritizing the tasks for assignment. The proposed heuristics has been illustrated with an example and the results have been compared to the heuristic proposed by McGovern and Gupta. The proposed heuristic performs well and has shown improvements in terms of cycle time and idle time of the workstations. Finally, Kabir and Sumi [9] propose a simple, systematic and logical scientific approach to evaluate power substation location through integrating fuzzy AHP with PROMETHEE. The proposed integrated approach provides more realistic and reliable results, and facilitates the decision-maker to handle multiple contradictory decision perspectives through eliminating the limitations of FAHP and PROMETHEE methods. To accredit the proposed model, it is implemented in a power substation location selection problem in Bangladesh.

Above mentioned papers are related to our study with similar methodology, now we mainly focus on the papers with close topics to our paper.

\subsection{Topic related literature}

Since our topic is the selection of 3D printers, we include the selection of rapid prototyping machines (first 3D printers) as our related topic.

Byun and Lee [10] deals with the selection of an optimal rapid prototyping system that best suits the end use of a part by using multiple attribute decision making and the test part designed with conjoint analysis to reflect users' preference. Evaluation factors that significantly affect the performance of an RP system such as accuracy, roughness, strength, elongation, parts cost and build time are presented as linguistic values that can be described with triangular fuzzy numbers and an appropriate rapid prototyping process is selected using a modified technique of order preference by a similarity to ideal solution (TOPSIS) method. Then, Roberson et al. [11] 
evaluates the capability of five desktop AM machines based on the ability to produce a standard component. Their work also developed a model/method for evaluating and ranking AM technologies based on select criteria that can facilitate purchasing decisions. The research highlights the differences between AM units and suggests a method by which to ascertain the differences. In another recent study Agarwal et al. [12] focuses on a hybrid multiple-criteria decision making tool for selecting an appropriate 3D printer based on the Deng's Similarity based approach. Both analytic network process (ANP) and similarity based method have been used to rank the alternatives according to the desired criteria. While ANP gives the proper weight age of the criteria taking into consideration the consequences and priorities, the similarity based method ranks them accordingly considering the human choice as well. Terminally, Kek et al. [13] aims to select environmentally friendlier Rapid Prototyping processes without compromising required mechanical properties. A conceptual model comprising 25 criteria (both traditional and environmental) has been developed. A Fuzzy ANP-TOPSIS methodology has been adopted for this purpose. Finally, a decision support system has been developed using MATLAB software to mitigate the associated computational difficulty.

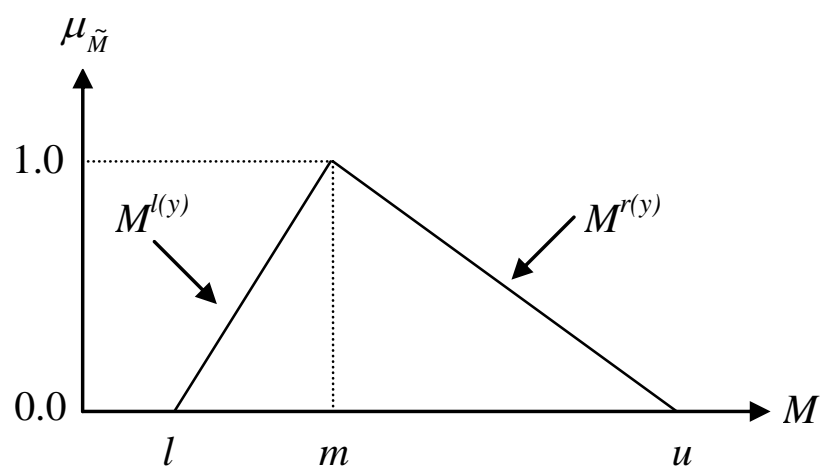

Figure 1. A triangular fuzzy number, $\tilde{M}$
As it can be realized there is no study in literature that uses Fuzzy AHP and PROMETHEE for selecting a 3D printer. Thus we apply this state of art hybrid technique for determining the best 3D printer for the company. Next we define the selection criteria obtained from the company.

\section{APPLIED METHODS}

This section first presents a brief introduction on Fuzzy Set Theory, AHP and PROMETHEE methods, followed by the same for proposed integrated approach.

\subsection{The Fuzzy Set Theory and Analytic Hierarchy Process}

Human judgment on qualitative attributes is always subjective and imprecise. Therefore, the fuzzy set theory is commonly used in decision making problems based on human judgements. Fuzzy numbers expand on the idea of the confidence interval and are defined over a fuzzy subset of real numbers. A triangular fuzzy number (TFN) shown in Figure 1 is a type of fuzzy number and, should possess the some basic properties [14].

A fuzzy number $\tilde{M}$ defined on $\mathfrak{R}$ is a TFN if its membership function $\mu_{\tilde{M}}(y): \mathfrak{R} \rightarrow[0,1]$ is equal to

$\mu_{\tilde{M}}(y)= \begin{cases}(y-l) /(m-l), & l \leq y \leq m \\ (u-y) /(u-m), & m \leq y \leq u \\ 0, & \text { otherwise }\end{cases}$

(1)

where $l, u, m$ are real numbers and $l \leq m \leq u$. The linguistic variable scale and the corresponding TFNs used in this study are shown in Table 1.
Table 1. The fuzzy linguistic scale

\begin{tabular}{lcc}
\hline $\begin{array}{l}\text { Linguistic terms for } \\
\text { importance }\end{array}$ & TFN & $\begin{array}{c}\text { TFN } \\
\text { (reciprocal) }\end{array}$ \\
\hline $\begin{array}{l}\text { Equal important (E) } \\
\text { Weak important (W) }\end{array}$ & $1,1,1$ & $1,1,1$ \\
& $2,3,4$ & $1 / 4,1 / 3,1 / 2$
\end{tabular}

In this study, the fuzzy set theory is incorporated with AHP through an evaluation form that uses linguistic variables. The value of the linguistic variables that a DM has assigned to the pairwise comparison between each two criteria is converted into TFN scores. The AHP methodology which is applied for this paper is explained below.

The Analytic Hierarchy Process (AHP) was developed by Thomas L. Saaty in the 1970s and it is a practical multi-criteria decision making method to calculate weights/priorities. The method does not require special knowledge and can be simply applied. It allows individual or group decision making process, quantitative and qualitative values can be used in a pairwise comparison
Strong important (S)

Demonstrated important

(D) Absolute important (A)

$$
\begin{array}{ll}
4,5,6 & 1 / 6,1 / 5,1 / 4 \\
6,7,8 & 1 / 8,1 / 7,1 / 6
\end{array}
$$

$8,9,10 \quad 1 / 10,1 / 9,1 / 8$

and criteria weights are calculated by pairwise comparison of decision makers [15-16]. The readers can find details about the steps of AHP in different papers [17-19]. In this study, the fuzzy AHP approach is used to determine criteria weights.

\subsection{The PROMETHEE method}

The PROMETHEE (Preference Ranking Organization METHod for Enrichment of Evaluations) is a MCDM method introduced by Brans and Vincke [20] and developed by Brans et al. [21]. It is well adapted to problems where a finite number of alternatives are to be ranked according to several, sometimes conflicting criteria by using six different functions [22]. The 
evaluation table is the starting point of the PROMETHEE method. Alternatives are evaluated according to the different criteria and preferences ( $\mathrm{min} / \mathrm{max}$, criteria weights, preference functions, thresholds) are declared in the evaluation table. The implementation of PROMETHEE requires two additional types of information; criteria weight and DMs' preference function. The weights coefficients can be determined with different methods [23, 24]. AHP method is used to determine the criteria weights in this study. Researchers can find easily the detailed steps of PROMETHEE method in different papers $[25,26]$.

\subsection{Proposed methodology}

The integrated approach -combination of fuzzy AHP and PROMETHEE methods- for the 3D printer selection problem consists of 3 basic stages: (1) determination of criteria, (2) fuzzy AHP computations to prioritize the criteria, (3) PROMETHEE computations to rank the alternatives. In the first stage, criteria and sub-criteria used for evaluating 3D printers are derived first from the literature and experts' opinions. Alternative machines are determined and the hierarchical structure is formed. In the last step of the first stage, the decision model is approved by experts. Following determination of the hierarchical structure and the approval of the decision model, evaluation of criteria with fuzzy AHP is realized in the second stage. In this phase, pairwise comparison matrices are formed to determine the criteria weights. The experts make individual evaluations to compare the criteria linguistically. Then the linguistic evaluations are converted to triangular fuzzy numbers (TFN). Computing the geometric mean of the values obtained from individual evaluations, a final pairwise comparison matrix on which there can be a consensus found. The local weights of the criteria and sub-criteria by using pairwise comparison matrices are determined. At the last step of this phase, after calculated weights of the criteria are approved by decision making team and the crisp values for fuzzy weights are calculated. After the determination the relative weights of qualitative criteria, these weights are used as coefficients of PROMETHEE model in the third stage. Preference functions and parameters to be used for PROMETHEE computations are determined by the decision making team. After the approval of the functions -partial ranking with PROMETHEE-I- complete ranking with PROMETHEE-II and GAIA plane are determined by using Decision Lab software. In the last step of the proposed procedure, the best $3 \mathrm{D}$ printer is selected according to the ranking results. Schematic representation of the proposed approach is presented in Figure 2.

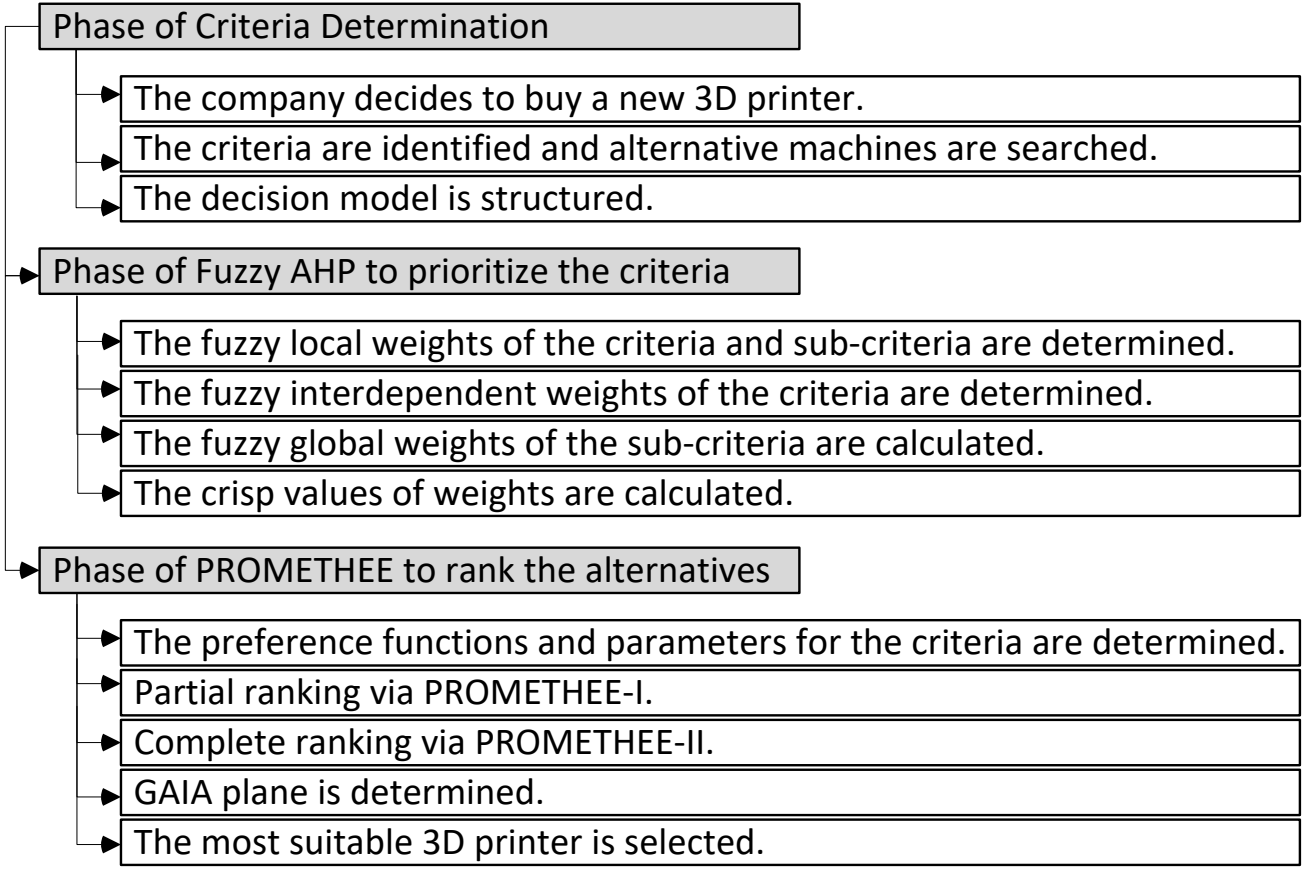

Figure 2. Schematic representation of the proposed approach

\section{A REAL CASE APPLICATION}

The proposed 3D printer selection model discussed herein is applied in a R\&D company, which operates in 3D production industry for 2 years, located in Gaziantep Technopolis. The company would like to purchase a 3D printer to increase its efficiency and reduce cost at long terms by replacing its traditional machines. It is a known fact that the high technology $3 \mathrm{D}$ printers make significant improvements in the manufacturing processes and correct decisions made at this stage can bring competitive advantage to the companies. There a lot of $3 \mathrm{D}$ printer brands in practice to choose one among them [27]. Therefore, selecting the most suitable $3 \mathrm{D}$ printer is very important for the company and it is hard to determine the most suitable one which dominates each of them in varying characteristics. 


\subsection{Phase of criteria determination}

Firstly the decision making team, which take a part in 3D printer selection process, is formed. The decision committee comprised of two industrial engineers working for the company and one advisor is constructed. Subsequently, a detailed interview is carried out with the committee to settle evaluation criteria and $3 \mathrm{D}$ printer alternatives. In this stage, a questionnaire concerning the assessment of the qualitative and quantitative criteria for the 3D printer is prepared and conducted. With a preliminary work, this decision making team determined five possible $3 \mathrm{D}$ printers suitable for the needs and budget of the company. Consequently, 17 evaluation criteria are determined. These criteria can be grouped into four main criteria namely technical, economic, performance and environmental. Decision hierarchy structured with the determined alternative printers and criteria is provided in Figure 3.

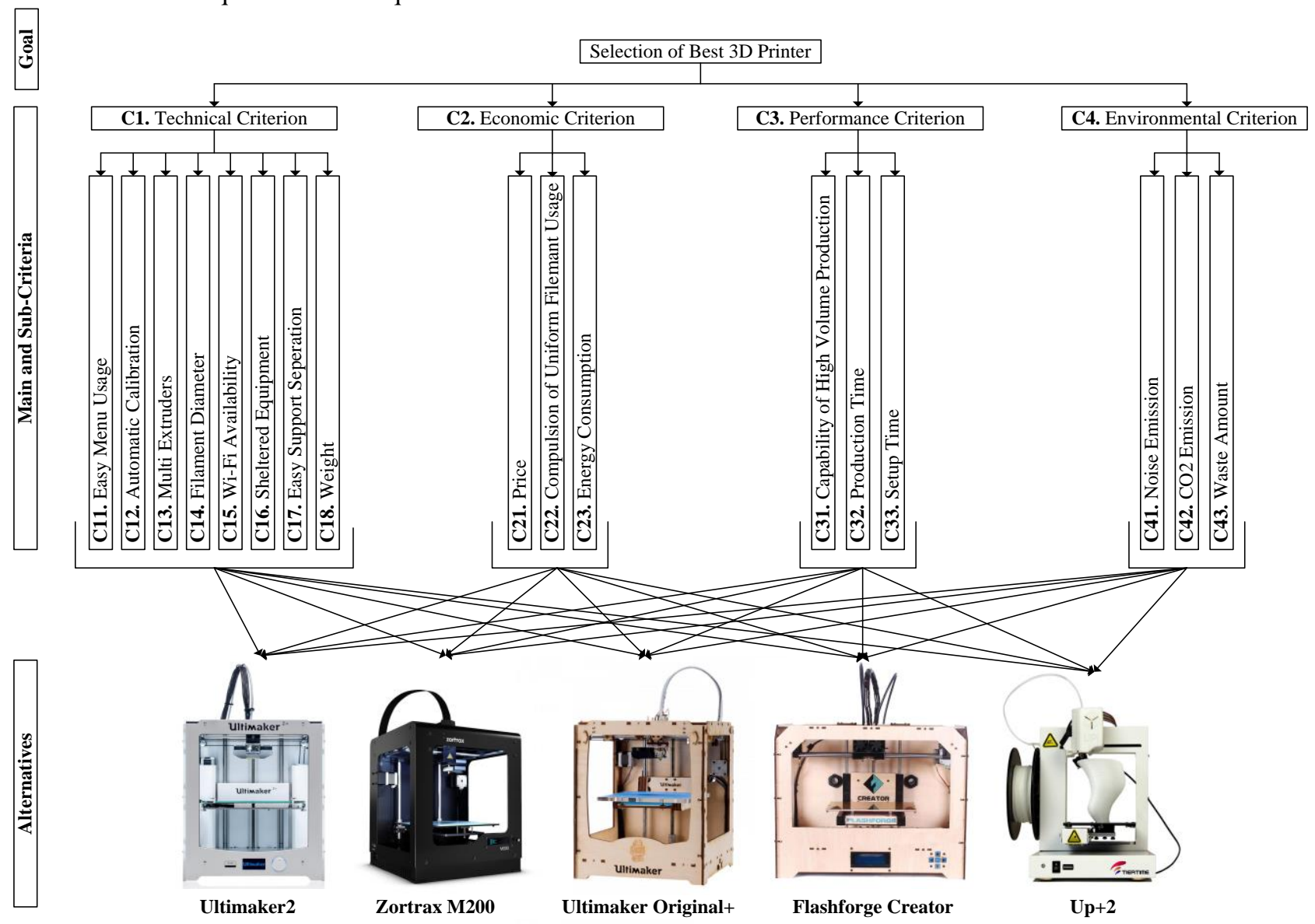

Figure 3. Hierarchy structure of the 3D printer selection

\subsection{Phase of Fuzzy AHP to prioritize the criteria}

The proposed model is composed of 3 stages. The first one includes the objective of the model, determined as selection of the best 3D printer. The second step includes criteria to be used in the measurement of printer selection. The main criteria are connected to the goal with a single directional arrow and the sub criteria are connected to the main criterion. The arrows represent the dependence to the goal or main criteria.

Local weights of the criteria and sub-criteria are calculated. Pairwise comparison matrices are formed by the experts by using the scale given in Table 1 and and local and global weights are given in Table 4. geometric means of experts' evaluations are used to calculate weights. For example technical criterion (C1) are compared with economic criterion (C2) using the question "Which is considered more important by the users choosing the 3D printer, and how much more important is it with respect to satisfaction with the $3 \mathrm{D}$ printer?" All the evaluation matrices are produced in the same manner. Pairwise comparison matrices for main criteria and sub-criteria for the economic criterion are given in Tables 2 and 3 respectively with the calculated local weights. The other comparison matrices are formed 
Table 2. Local weights and pairwise comparison matrix of criteria

\begin{tabular}{|c|c|c|c|c|c|c|c|c|c|c|c|c|c|c|c|}
\hline & \multicolumn{3}{|c|}{$\mathrm{C1}$} & \multicolumn{3}{|c|}{$\mathrm{C} 2$} & \multicolumn{3}{|c|}{ C3 } & \multicolumn{3}{|c|}{$\mathrm{C4}$} & \multicolumn{3}{|c|}{ Weights } \\
\hline & $l$ & $m$ & $\boldsymbol{u}$ & $l$ & $m$ & $\boldsymbol{u}$ & $l$ & $m$ & $u$ & $l$ & $m$ & $\boldsymbol{u}$ & $l$ & $m$ & $u$ \\
\hline C1 & 1.00 & 1.00 & 1.00 & 2.52 & 3.56 & 4.58 & 2.00 & 2.47 & 2.88 & 6.00 & 7.00 & 8.00 & 0.42 & 0.50 & 0.58 \\
\hline $\mathrm{C} 2$ & 0.22 & 0.28 & 0.40 & 1.00 & 1.00 & 1.00 & 0.22 & 0.28 & 0.40 & 4.58 & 5.59 & 6.60 & 0.12 & 0.15 & 0.18 \\
\hline $\mathrm{C3}$ & 0.35 & 0.41 & 0.50 & 2.52 & 3.56 & 4.58 & 1.00 & 1.00 & 1.00 & 4.58 & 5.59 & 6.60 & 0.25 & 0.30 & 0.35 \\
\hline \multirow[t]{4}{*}{$\mathrm{C} 4$} & 0.13 & 0.14 & 0.17 & 0.15 & 0.18 & 0.22 & 0.15 & 0.18 & 0.22 & 1.00 & 1.00 & 1.00 & 0.04 & 0.05 & 0.05 \\
\hline & \multicolumn{15}{|c|}{ Table 3. Pairwise comparison matrices based on economic criterion } \\
\hline & \multicolumn{4}{|c|}{$\mathbf{C 2 1}$} & \multicolumn{4}{|c|}{$\mathbf{C 2 2}$} & \multicolumn{3}{|c|}{$\mathbf{C 2 3}$} & \multicolumn{4}{|c|}{ Weights } \\
\hline & $l$ & & $m$ & $\boldsymbol{u}$ & $l$ & $m$ & & $u$ & $l$ & $m$ & $\boldsymbol{u}$ & $l$ & & $m$ & $\boldsymbol{u}$ \\
\hline $\mathbf{C 2 1}$ & 1.0 & & .00 & 1.00 & 3.63 & 4.72 & & 77 & 6.60 & 7.61 & 8.62 & 0.64 & & 0.73 & 0.81 \\
\hline $\mathrm{C} 22$ & 0.1 & & .21 & 0.28 & 1.00 & 1.00 & & 00 & 2.52 & 3.56 & 4.58 & 0.17 & & 0.20 & 0.24 \\
\hline $\mathrm{C} 23$ & 0.12 & & .13 & 0.15 & 0.22 & 0.28 & & 40 & 1.00 & 1.00 & 1.00 & 0.06 & & 0.07 & 0.09 \\
\hline
\end{tabular}

Table 4. Computed global weights for sub-criteria

\begin{tabular}{|c|c|c|c|c|c|c|c|c|c|c|c|}
\hline \multirow[t]{2}{*}{ Factors } & \multicolumn{3}{|c|}{ Weights } & \multirow[t]{2}{*}{ Factors } & \multicolumn{3}{|c|}{ Weights } & \multicolumn{3}{|c|}{ Global Weights } & \multirow[t]{2}{*}{ Crisp Weights } \\
\hline & $l$ & $m$ & $u$ & & $l$ & $m$ & $\boldsymbol{u}$ & $l$ & $m$ & $u$ & \\
\hline \multirow{9}{*}{$\mathrm{C} 1$} & \multirow{8}{*}{0.42} & \multirow{8}{*}{0.50} & \multirow{8}{*}{0.58} & $\mathrm{C} 11$ & 0.021 & 0.026 & 0.035 & 0.009 & 0.013 & 0.020 & 0.014 \\
\hline & & & & $\mathrm{C} 12$ & 0.072 & 0.088 & 0.105 & 0.030 & 0.044 & 0.061 & 0.046 \\
\hline & & & & $\mathrm{C} 13$ & 0.255 & 0.302 & 0.345 & 0.107 & 0.152 & 0.199 & 0.155 \\
\hline & & & & $\mathrm{C} 14$ & 0.296 & 0.338 & 0.378 & 0.125 & 0.170 & 0.218 & 0.173 \\
\hline & & & & $\mathrm{C} 15$ & 0.069 & 0.086 & 0.106 & 0.029 & 0.043 & 0.061 & 0.045 \\
\hline & & & & $\mathrm{C} 16$ & 0.059 & 0.070 & 0.083 & 0.025 & 0.035 & 0.048 & 0.036 \\
\hline & & & & $\mathrm{C} 17$ & 0.047 & 0.057 & 0.070 & 0.020 & 0.029 & 0.040 & 0.030 \\
\hline & & & & $\mathrm{C} 18$ & 0.027 & 0.033 & 0.040 & 0.012 & 0.016 & 0.023 & 0.017 \\
\hline & \multirow{3}{*}{0.12} & \multirow{3}{*}{0.15} & \multirow{3}{*}{0.18} & $\mathrm{C} 21$ & 0.635 & 0.726 & 0.810 & 0.078 & 0.107 & 0.147 & 0.111 \\
\hline \multirow[t]{2}{*}{$\mathrm{C} 2$} & & & & $\mathrm{C} 22$ & 0.167 & 0.200 & 0.238 & 0.021 & 0.029 & 0.043 & 0.031 \\
\hline & & & & $\mathrm{C} 23$ & 0.065 & 0.073 & 0.086 & 0.008 & 0.011 & 0.016 & 0.011 \\
\hline \multirow{3}{*}{ C3 } & \multirow{3}{*}{0.25} & \multirow{3}{*}{0.30} & \multirow{3}{*}{0.35} & C31 & 0.486 & 0.533 & 0.574 & 0.124 & 0.162 & 0.204 & 0.165 \\
\hline & & & & C32 & 0.369 & 0.402 & 0.441 & 0.000 & 0.122 & 0.156 & 0.102 \\
\hline & & & & C33 & 0.059 & 0.064 & 0.071 & 0.000 & 0.020 & 0.025 & 0.016 \\
\hline \multirow{3}{*}{$\mathrm{C} 4$} & \multirow{3}{*}{0.04} & \multirow{3}{*}{0.05} & \multirow{3}{*}{0.05} & C41 & 0.47 & 0.53 & 0.57 & 0.020 & 0.025 & 0.031 & 0.025 \\
\hline & & & & $\mathrm{C} 42$ & 0.07 & 0.08 & 0.09 & 0.003 & 0.004 & 0.005 & 0.004 \\
\hline & & & & $\mathrm{C} 43$ & 0.36 & 0.40 & 0.44 & 0.015 & 0.019 & 0.024 & 0.019 \\
\hline
\end{tabular}

According to the results, C14 (Filament Diameter), C31 (Capability of High Volume Production) and C13 (Multi Extruders) are determined as the three most important sub-criteria, respectively considering 3D printer satisfaction.

\subsection{Phase of PROMETHEE to rank the alternatives}

In this phase, firstly alternative 3D printers are evaluated based on the sub-criteria and the evaluation matrix is formed as shown in Figure 4. Before using the PROMETHEE method to rank the alternative 3D printers, for each criterion, a specific preference function (PF) with its thresholds is defined. Preference functions and threshold values have been defined by the experts. The preference functions and threshold values defined by the experts in this paper are special for this application, every researcher reading this paper must define his own values in his $3 \mathrm{D}$ printer selection process. 


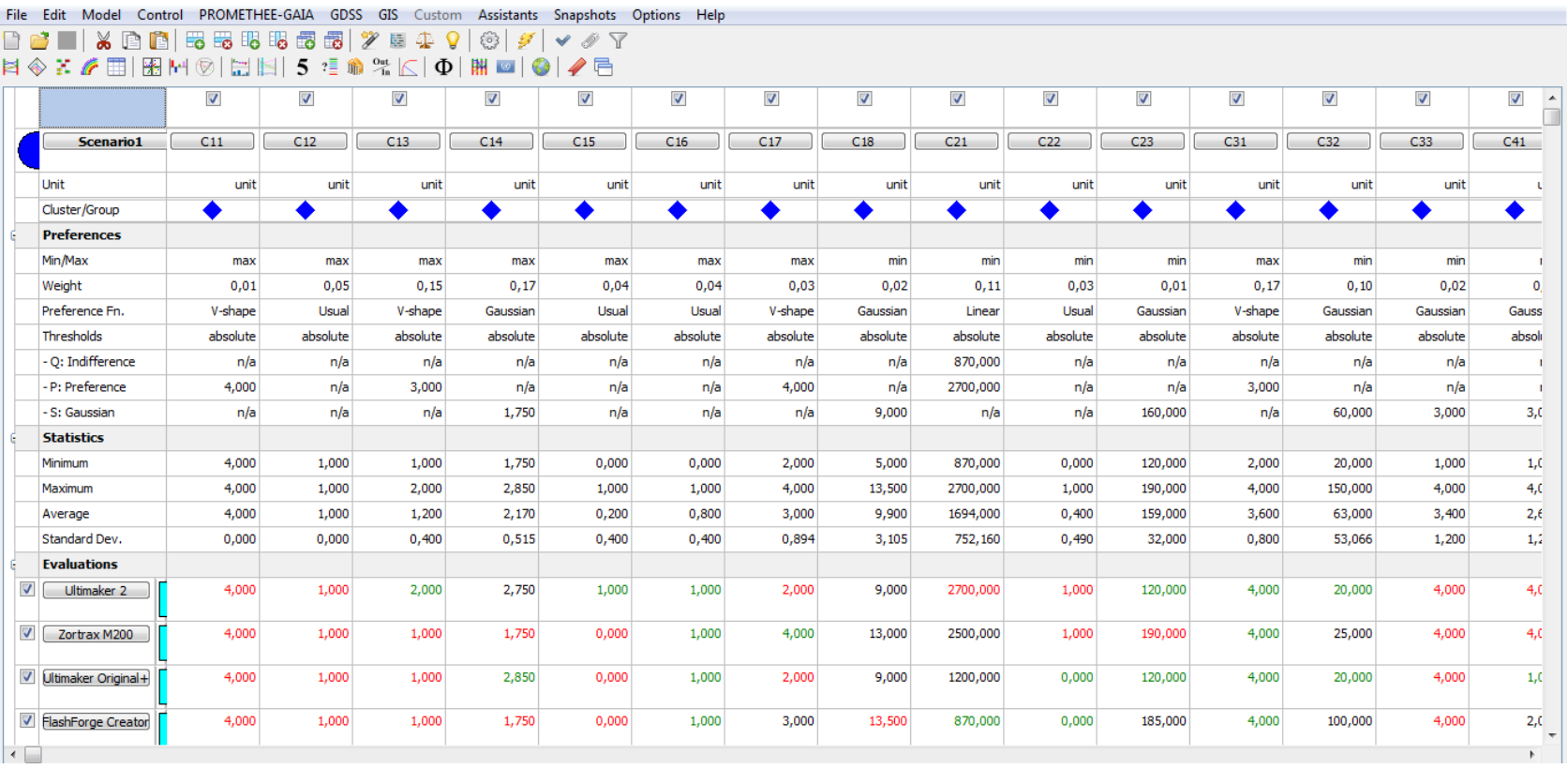

Figure 4. Evaluation values for alternatives

Since different preference functions, number of criteria and alternatives make calculations difficult in PROMETHEE method; an open access software program namely Decision Lab is used. The positive flow (Phi+), negative flow (Phi-) and net flow (Phi) values obtained from this evaluation are given in Figure 4. The alternatives are ranked in the order of Ultimaker 2, Ultimaker Original+, FlashForge Creator, Zortrax M200 and $\mathrm{Up}+2$ according to Phi values as shown in Figure 5.

\begin{tabular}{|c|c|c|c|c|c|}
\hline Rank & action & & Phi & Phit & Phi- \\
\hline 1 & Ultimaker 2 & $\square$ & 0,1124 & 0,1924 & 0,0801 \\
\hline 2 & Ultimaker Original+ & $\square$ & 0,0944 & 0,1367 & 0,0423 \\
\hline 3 & FlashForge Creator & $\square$ & 0,0006 & 0,0943 & 0,0937 \\
\hline 4 & Zortrax M200 & $\square$ & $-0,0124$ & 0,0857 & 0,0980 \\
\hline 5 & $U p+2$ & $\square$ & $-0,1950$ & 0,0663 & 0,2613 \\
\hline
\end{tabular}

Figure 5. Ranking for 3D printers

The decision problem can be represented in the GAIA (Geometrical Analysis for Interactive Aid) plane where alternative $3 \mathrm{D}$ printers are represented by points and criteria by vectors. In this way, conflicting criteria may appear clearly. Criteria vectors expressing similar

Vector pi (decision axis) represents the direction of the compromise derived from the assignment; the decision maker is invited to appreciate the alternative 3D printers located in that direction [28]. It can be seen from figure that $p i$ vector is in the direction of criterion $\mathrm{C} 16$ - criterion $\mathrm{C} 31$ and the closest alternatives to the pi vector are Ultimaker Original+, Zortrax M200 and Ultimaker 2. This result is consistent with the ranking of PROMETHEE method. preferences on the data are oriented in the same direction, while conflicting criteria are pointing in opposite directions. The length of each vector is a measure of its power in alternative $3 \mathrm{D}$ printer differentiation. This plane is the result of principal component analysis (PCA), projecting the 17-dimensional space of criteria onto a two-dimensional plane, i.e. the 17 original variables are transformed to the two new variables that are obtained by two linear combinations of the original variables. In the PCA process, criteria are handled by the linear combinations to prevent double counting [22]. As it is shown in the Figure 6, the Delta-parameter is $83.5 \%$; this means only $16.5 \%$ of the total information gets lost by the projection.

It can be observed that $\mathrm{C} 16$ and $\mathrm{C} 22$ have a high differentiation power and expresses independent preferences, different from those expressed by most of all other criteria. A cluster of conflicting criteria (C31 and C43 expressing opposite preferences) are clearly represented. It is also possible to appreciate clearly the quality of the alternative $3 \mathrm{D}$ printers with respect to the different criteria. FlashForge Creator is particularly good on $\mathrm{C} 22$ and C41. Ultimaker 2 is good on C13 and C15.

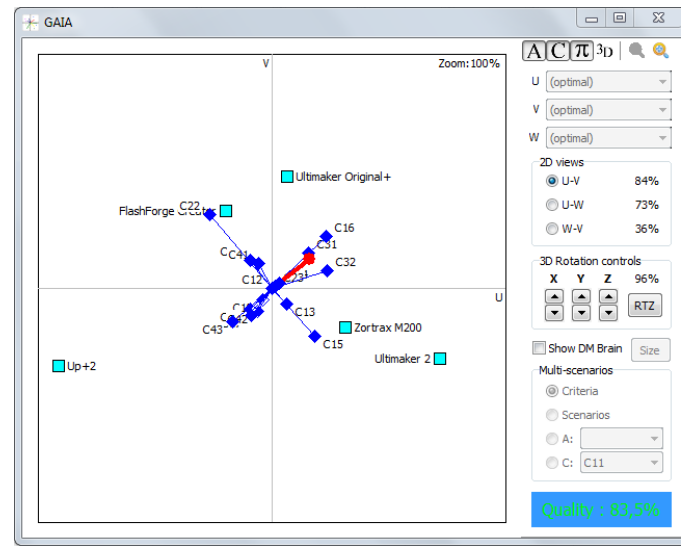

Figure 6. GAIA Plane for 3D printers' selection 


\subsubsection{Managerial Insights}

In this section, we present the results of two different scenario analyses to provide insights for the managers of the company. The former presents sensitivity analysis to reveal the effect of changing the priority of highest weighted criteria; in the latter, different combinations of FAHP and PROMETHEE techniques are compared on $3 \mathrm{D}$ printer selection.

Sensitivity analysis on criteria weights: In this subanalysis, the weight of the most significant criteria, C14, is increased and decreased by $10 \%, 20 \%, 30 \%$, and $40 \%$ of the original value, giving eight new weight values for C14. New weights of criteria after changing the weight of criteria $\mathrm{C} 14$ are shown in Figure 7. As it seen from Figure 7 , while some of the weights of criteria are changed, some of them are not affected. For instance, weights of $\mathrm{C} 17$, $\mathrm{C} 18, \mathrm{C} 22, \mathrm{C} 23, \mathrm{C} 42$ and $\mathrm{C} 43$ are remained unchanged. Conversely, increasing the weight of $\mathrm{C} 14$ decreases the weights of $\mathrm{C} 11, \mathrm{C} 12, \mathrm{C} 13, \mathrm{C} 15, \mathrm{C} 16, \mathrm{C} 21, \mathrm{C} 31, \mathrm{C} 32$, $\mathrm{C} 33$ and $\mathrm{C} 41$. It is noted that sensitivity analysis on highest weighted criteria does not make any sense on ranking. Ranking shown in Figure 5 is valid for all criteria weight combinations. This result shows that obtained ranking of $3 \mathrm{D}$ printers is robust.

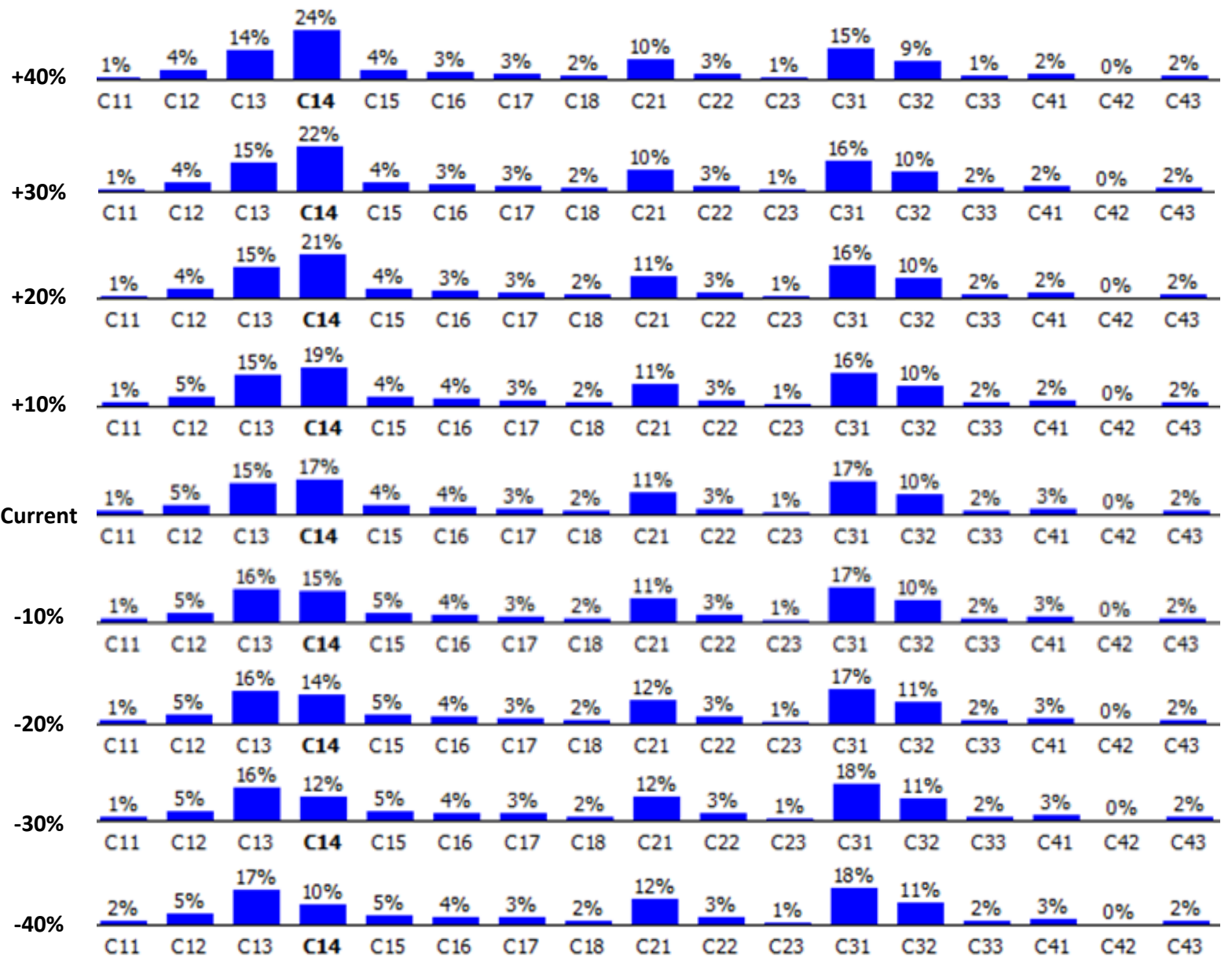

Figure 7. Sensitivities on weight of $\mathrm{C} 14$

Sensitivity analysis on different applications: In addition to current FAHP and PROMETHEE approach, following approaches are also applied in this sub-analysis.

- FAHP

- FAHP (equal weights)
- PROMETHEE (equal weights)

- FAHP and PROMETHEE (functions as usual) Results obtained by aforementioned approaches are given in Table 5.

Table 5. Alternatives' ranking based on scenarios

\begin{tabular}{lccccc}
\hline \multicolumn{1}{c}{ Applied Approaches / Alternatives } & Ultimaker2 & $\begin{array}{c}\text { Zortrax } \\
\text { M200 }\end{array}$ & $\begin{array}{c}\text { Ultimaker } \\
\text { Original+ }\end{array}$ & $\begin{array}{c}\text { Flashforge } \\
\text { Creator }\end{array}$ & Up+2 \\
\hline FAHP (Equal Weights) & 1 & 2 & 4 & 3 & 5 \\
FAHP (Weighted) & 1 & 2 & 3 & 4 & 5 \\
PROMETHEE (Equal Weights) & 2 & 5 & 1 & 3 & 4 \\
FAHP-PROMETHEE (Functions as & 2 & 4 & 1 & 3 & 5 \\
Usual) & 1 & 4 & 2 & 3 & 5 \\
FAHP-PROMETHEE (Current approach) & & &
\end{tabular}


As it is seen from Table 5, rankings obtained by applied approaches are different from each other. However, some of the printers fall into the same place. For instance, Flashforge Creator and Up+2 printers are located in third and fifth ranks, respectively. On the contrary, Ultimaker2 and Ultimaker Original+ printers take place near the top. These average rankings support the result of current approach. Managers of the company already confirmed the rank obtained by current approach.

\section{CONCLUSION AND FUTURE RESEARCH}

3D printers are changing the commerce working system. The companies do not need to build expensive manufacturing facilities, they do not need to hire numerous workers or purchase large storage spaces for inventory in order to produce a product. 3D printers can handle the same process only by uploading a file. Also it causes cost savings and lesser production times, it brings creativity freedom and it is more environmental friendly.

Choosing a 3D printer can be imagined as choosing any device for one's needs. It depends largely on the budget. Paying higher prices may ensure high quality prints and it brings more features thus affecting the printer's output quality. So choosing a 3D printer can be challenging. Before choosing a 3D printer, the users should think carefully on the purpose of their usage and need to determine all the important specifications they need.

Thus in this paper, the real 3D printer selection problem of a 3D production company in Gaziantep/Turkey is taken into account. To analyze their needs and to solve the problem, the selection criteria are obtained from the company firstly. Then, selection criteria are prioritized using FAHP and potential 3D printers are ranked using PROMETHEE. According to the results, Filament Diameter, Capability of High Volume Production and Multi Extruders are determined as the three most important sub-criteria.

Different perspectives are generated in scenario analysis to provide managerial insight. For future research; a different selection problem for 3D printers can be handled such as filament type selection or different selection methods can be used for 3D printer selection.

\section{ACKNOWLEDGMENTS}

The authors express sincere appreciation to the editor and anonymous reviewers for their efforts to improve the quality of this paper. Third author was supported by the BAGEP Award of the Science Academy in Turkey.

\section{REFERENCES}

[1] Conner, B.P., Manogharan, G.P., Martof, A.N., Rodomsky, L.M., Rodomsky, C.M., Jordan, D.C., Limperos, J.W., 2014, Making sense of 3D printing: Creating a map of additive manufacturing products and services, Additive Manufacturing, 1-4: 64-76.

[2] Cetinkaya, C., Ozceylan, E., 2015, Impacts of 3D Printing on Supply Chain Management, In proceedings of $13^{\text {th }}$ International Logistics and Supply Chain Conference, pp. 649-657.
[3] Berman, B., 2012, 3D printing: The new industrial revolution, Business Horizons, 55: 155-162.

[4] Akça, B.A., Doğan, A., Özcan, U., 2015, Analitik Hiyerarşi Süreci Kullanılarak Kişi Takip Cihazı Seçimi, International Journal of Informatics Technologies, 8 (1): 20-35.

[5] Rao, R.V., Patel, B.K., 2010, Decision making in the manufacturing environment using an improved PROMETHEE method, International Journal of Production Research, 48 (16): 4665-4682.

[6] Alp, Ö.N., Demirtaş, N., Baraçlı, H., Tuzkaya, U.R., 2011, Fuzzy AHP-PROMETHEE methodology to select bus garage location: A case study for a firm in the urban passenger transport sector in İstanbul, $15^{\text {th }}$ International Research/Expert Conference on Trends in the Development of Machinery and Associated Technology, pp. 273-276.

[7] Brajlih, T., Valentan, B., Balic, J., Drstvensek, I., 2011, Speed and accuracy evaluation of additive manufacturing machines, Rapid Prototyping Journal, 17 (1): 64-75.

[8] Taha, Z., Rostam, S., 2012, A hybrid fuzzy AHP-PROMETHEE decision support system for machine tool selection in flexible manufacturing cell, Journal of Intelligent Manufacturing, 23: 21372149 .

[9] Avikal, S., Mishra, P.K., Jain, R., 2014, A Fuzzy AHP and PROMETHEE method-based heuristic for disassembly line balancing problems, International Journal of Production Research, 52 (5): 1306-1317.

[10] Kabir, G., Sumi, R.Z., 2014, Power substation location selection using fuzzy analytic hierarchy process and PROMETHEE: A case study from Bangladesh, Energy, 72: 717-730.

[11] Byun, H.S., Lee, K.H., 2005, A decision support system for the selection of a rapid prototyping process using the modified TOPSIS method, International Journal of Advanced Manufacturing Technology, 26: 1338-1347.

[12]Roberson, D.A., Espalin, D., Wicker, R.B., 2013, 3D printer selection: A decision-making evaluation and ranking model, Virtual and Physical Prototyping, 8 (3): 201-212.

[13]Agarwal, P.K., Paul, D., Choudhury, S.R., Banerjee, D., 2015 Selection of 3D printers for educational institutions using ANPSimilarity based approach, International Journal of Engineering Research and Technology, 4 (4): 278-287.

[14]Kek, V., Vinodh, S., Brajesh, P., Muralidharan, R., 2016, Rapid prototyping process selection using multi criteria decision making considering environmental criteria and its decision support system, Rapid Prototyping Journal, 22 (2): 225-250.

[15]Facchinetti, G., Ricci, R.G., 2004, A characterization of a general class of ranking functions on triangular fuzzy numbers, Fuzzy Sets and Systems 146 (2): 297-312.

[16]Saaty, T.L., 1977, A scaling method for priorities in hierarchical structures, Journal of Mathematical Psychology, 15 (3): 234-281.

[17]Saaty, T.L., 1980, The analytic hierarchy process, New York, McGraw-Hill International.

[18]Saaty, T.L., 1996, Decision making with dependence and feedback: The analytic network process, Pittsburgh, RWS Publications.

[19]Pourghasemi, H.R., Pradhan, B., Gokceoglu, C., 2012, Application of fuzzy logic and analytical hierarchy process (AHP) to landslide susceptibility mapping at Haraz watershed, Iran, Natural Hazards, 63 (2): 965-996.

[20]Qdais, H.A., Alshraideh, H., 2016, Selection of management option for solid waste from olive oil industry using the analytical hierarchy process, Journal of Material Cycles and Waste Management, 18 (1): $177-185$.

[21]Brans, J.P., Vincke, P.H., 1985, A preference ranking organization method, Management Science 31 (6): 647-656. 
22]Brans, J.P., Vincke, P.H., Mareschall, B., 1986, How to select and how to rank projects: The PROMETHEE method, European Journal of Operational Research, 24 (2): 228-238.

[23] Albadvi, A., Chaharsooghi, S.K., Esfahanipour, A., 2007, Decision making in stock trading: An application of PROMETHEE, European Journal of Operational Research, 177 (2): 673-683.

[24]Nijkamp, P., Rietveld, P., Voogd, H., 1990, Multi-criteria evaluation in physical planning, Amsterdam, Elsevier Science Publishers.

[25]Mergias, I., Moustakas, K., Papadopoulos, A., Loizidou, M., 2007, Multi-criteria decision aid approach for the selection of the best compromise management scheme for ELVs: The case of Cyprus, Journal of Hazardous Materials, 147 (3): 706-717.
[26]Kabak, M., Dağdeviren, M., 2014, A hybrid MCDM approach to assess the sustainability of students' preferences for university selection, Technological and Economic Development of Economy, 20 (3): 391-418.

[27]Kadziński, M., Ciomek, K., 2016, Integrated framework for preference modeling and robustness analysis for outranking-based multiple criteria sorting with ELECTRE and PROMETHEE, Information Sciences, 352-353: 167-187.

[28]3D printers and 3D printing news, 2017, List of 3D manufacturers, http://www.3ders.org/pricecompare/3dprinters/Access date: 28.01.2017.

[29] Wang J.J., Yang, D.L., 2007, Using a hybrid multi-criteria decision aid method for information systems outsourcing, Computers and Operation Research, 34 (12): 3691-3700. 